\title{
Photosynthetic activity buffers ocean acidification in seagrass meadows
}

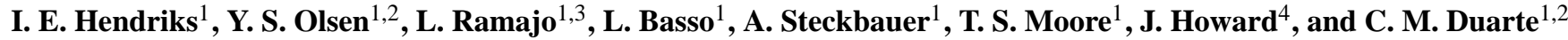 \\ ${ }^{1}$ Global Change department, IMEDEA (CSIC-UIB), Instituto Mediterráneo de Estudios Avanzados, C/ Miquel Marqués 21, \\ 07190 Esporles (Mallorca), Spain \\ ${ }^{2}$ The UWA Oceans Institute and School of Plant Biology, University of Western Australia, 35 Stirling Highway, \\ Crawley WA 6009, Australia \\ ${ }^{3}$ Laboratorio de Ecologia y Cambio Climatico, Facultad de Ciencias Universidad Santo Tomás, C/ Ejercito 146, \\ Santiago de Chile, Chile \\ ${ }^{4}$ Department of Biological Sciences, Florida International University, 11200 SW 8th Street, Miami, FL 33199, USA
}

Correspondence to: I. E. Hendriks (iris@imedea.uib-csic.es)

Received: 30 May 2013 - Published in Biogeosciences Discuss.: 22 July 2013

Revised: 6 December 2013 - Accepted: 9 December 2013 - Published: 28 January 2014

\begin{abstract}
Macrophytes growing in shallow coastal zones characterised by intense metabolic activity have the capacity to modify $\mathrm{pH}$ within their canopy and beyond. We observed diel $\mathrm{pH}$ changes in shallow (5-12 m) seagrass (Posidonia oceanica) meadows spanning $0.06 \mathrm{pH}$ units in September to 0.24 units in June. The carbonate system (pH, DIC, and aragonite saturation state $\left.\left(\Omega_{\mathrm{Ar}}\right)\right)$ and $\mathrm{O}_{2}$ within the meadows displayed strong diel variability driven by primary productivity, and changes in chemistry were related to structural parameters of the meadow, in particular, the leaf surface area available for photosynthesis (LAI). LAI was positively correlated to mean, max and range $\mathrm{pH}_{\mathrm{NBS}}$ and max and range $\Omega_{\mathrm{Ar}}$. In June, vertical mixing (as Turbulent Kinetic Energy) influenced max and min $\Omega_{\mathrm{Ar}}$, while in September there was no effect of hydrodynamics on the carbonate system within the canopy. Max and range $\Omega_{\text {Ar }}$ within the meadow showed a positive trend with the calcium carbonate load of the leaves, pointing to a possible link between structural parameters, $\Omega_{\mathrm{Ar}}$ and carbonate deposition.

Calcifying organisms, e.g. epiphytes with carbonate skeletons, may benefit from the modification of the carbonate system by the meadow. There is, however, concern for the ability of seagrasses to provide modifications of similar importance in the future. The predicted decline of seagrass meadows may alter the scope for alteration of $\mathrm{pH}$ within a seagrass meadow and in the water column above the meadow, particularly if shoot density and biomass decline, on which LAI is based.
\end{abstract}

Organisms associated with seagrass communities may therefore suffer from the loss of $\mathrm{pH}$ buffering capacity in degraded meadows.

\section{Introduction}

Forecasts predict that ocean acidification will become a significant threat to calcifying organisms in the near future (Orr et al., 2005; Gazeau et al., 2007; Talmage and Gobler, 2010; Waldbusser et al., 2011), many of which live in coastal habitats. However, coastal ecosystems are characterised by large temporal and spatial variability in carbonate chemistry and pH (Hofmann et al., 2011; Mercado and Gordillo 2011; Duarte et al., 2013), many of which regularly exceed predicted decreases in $\mathrm{pH}$. In highly productive ecosystems this variability follows daily and seasonal cycles as $\mathrm{O}_{2}$ and DIC concentrations in the water column are modulated through metabolic activity, with a signal that often prevails over physical forcing (Delille et al., 1997; Duarte et al., 2013). Whereas watershed effects can be a significant source of $\mathrm{pH}$ regulation and variability in coastal, estuarine waters, these are restricted in islands, where vulnerability to ocean acidification can only be offset by metabolic-intense ecosystems able to remove $\mathrm{CO}_{2}$ (Duarte et al., 2013). This is the case of Mediterranean islands, which have small watersheds and little or no runoff to the coast, but where seagrass, Posidonia 
oceanica, meadows support intense metabolism (Duarte and Chiscano, 1999; Duarte et al., 2010), possibly contributing to alleviate the expected impacts of ocean acidification.

Mediterranean Posidonia oceanica meadows are able to modify $\mathrm{pH}$ in the water column by as much as $0.2-$ $0.7 \mathrm{pH}$ units diurnally through photosynthetic activity and community metabolism (Frankignoulle and Distèche, 1984; Frankignoulle and Bouquegneau, 1990; Invers et al., 1997). The diurnal range in $\mathrm{pH}$ is greatest in shallow sites and the influence on the water column is diluted with increasing distance from the meadow (Invers et al., 1997), although the influence of the meadow stretches far beyond the canopy itself (Frankignoulle and Distèche, 1984; Gazeau et al., 2005). The magnitude of diurnal variations is largest in summer, coinciding with the peak in productivity, and decreases during the winter (Frankignoulle and Distèche, 1984). Whereas the capacity of Mediterranean $P$. oceanica meadows to affect $\mathrm{pH}$ is well characterised, and the relationship between $\mathrm{pH}$ variability, metabolic activity and water residence times in seagrass meadows have been described, not always a strong relationship is found. For instance Duarte et al. (2010) only found a weak relationship between biomass and metabolic rates; therefore detailed and simultaneous evaluation of several structural traits believed to drive these changes to assess which of those is the most important is still lacking. Focussing on the effect of structural traits on $\mathrm{pH}$ instead of direct measurements of metabolism has an advantage as approaches involving chambers, the most common approach in the literature to determine metabolism (Duarte et al., 2010), interferes with the effect of hydrodynamics and turbulent mixing; especially in systems with unidirectional flow, in buffering effects on $\mathrm{pH}$ and $\Omega$ aragonite $\left(\Omega_{\mathrm{Ar}}\right)$ and therefore might inflate the fluctuations in saturation states relative to those actually occurring in the meadow. Open water determinations of metabolism work best when there is a unidirectional flow, such as in tidal dominated systems, and a set-up with upstream and downstream sensors to properly resolve advection processes is used. However, this approach requires detailed knowledge of the origin of measured water bodies and therefore can be problematic in wave-dominated systems. Another advantage is that LAI is a non destructive method that can be easily assessed and can be resolved at large scales, thereby providing options to map where conditions may be most suitable for calcifiers, while metabolic rates over large scales would be cumbersome to derive.

Metabolic activity in highly productive seagrass meadows exposes marine organisms to $\mathrm{pH}$ environments that can differ greatly from those of the surrounding bulk water. Seagrasses may therefore provide chemical "refugia" for vulnerable organisms where photosynthetic activity may raise $\mathrm{pH}$ above the thresholds for impacts on calcification and/or limit the time spent below some critical $\mathrm{pH}$ threshold. There is evidence that organisms associated with seagrass meadows might benefit from this function. High $\mathrm{pH}$ values modified due to seagrass photosynthesis enhanced calcification

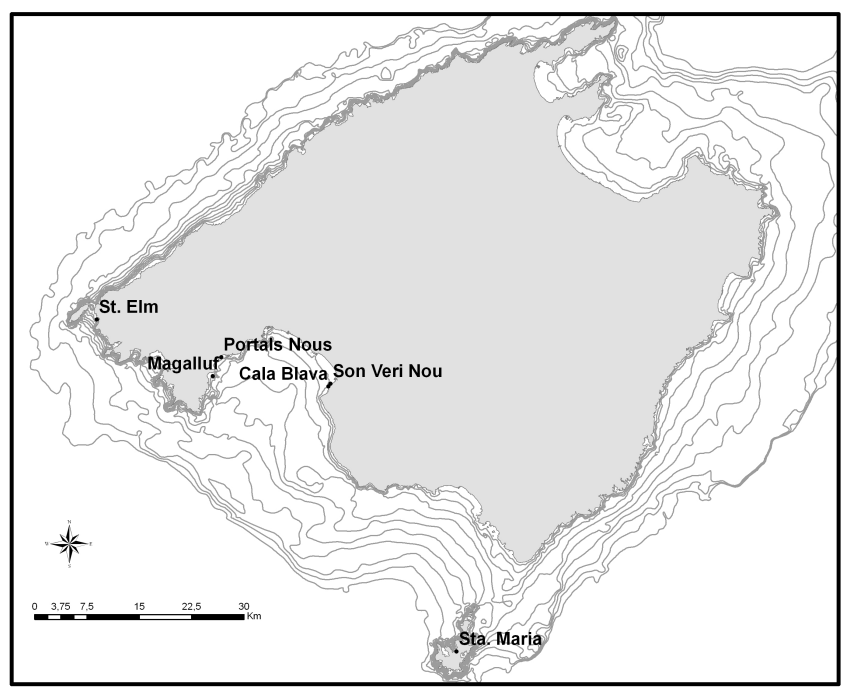

Fig. 1. Geographical location and sample sites of the study area in the Balearic Islands (western Mediterranean). Continuous lines show isobaths.

rates of calcareous red macroalgae (Hydrolithon sp. and Mesophyllum sp.) and the green macroalga Halimeda renschii growing within a tropical seagrass bed (Semesi et al., 2009). A recent model based on records of seagrass metabolism in the Indo-Pacific suggested that $\mathrm{pH}$ increases with hypothetical maxima of up to 0.38 units, and theoretical $\Omega_{\mathrm{Ar}}$ increases of up to 2.9 in seagrass meadows could potentially enhance calcification of scleratinian corals downstream of seagrasses by $18 \%$ (Unsworth et al., 2012). The drawdown of dissolved inorganic carbon (DIC) due to photosynthesis of algae can result in a local net increase of $\mathrm{pH}$ and $\Omega_{\mathrm{Ar}}$, while the spatial patterns of the benthic community structure (i.e. percent cover of algal and coral communities) affects the upstream - downstream patterns of carbonate chemistry and impacts overall calcification rates on reef flats (Kleypas et al., 2011). However, field investigations linking the mitigating capacity of metabolically intense macrophyte ecosystems to their structural parameters like LAI are lacking.

Here, we evaluate the effect of structural parameters (shoot density, leaf area index, biomass) of the meadow and the interaction with physical forcing (hydrodynamics) on the resulting carbonate system in the meadow during the period where these effects are likely to be more important, i.e. between June and September. We demonstrate that the metabolic effects of $P$. oceanica meadows on $\mathrm{pH}$ along the coast of Mallorca (Balearic islands, Spain) are closely related to structural parameters of the meadow. These effects are large enough as to possibly help mitigate the impacts of future ocean acidification for calcifying organisms associated with these meadows. 
Table 1. Mean $( \pm \mathrm{SD})$ environmental parameters (temperature in ${ }^{\circ} \mathrm{C}$, light intensity in lux), hydrodynamics ( \pm SE) and characteristics of the seagrass meadows (shoot density $( \pm \mathrm{SE})$, biomass, LAI) at the sites sampled in this study.

\begin{tabular}{|c|c|c|c|c|c|c|c|c|c|}
\hline Station & Plot & $\begin{array}{l}\text { Mean Temp. } \\
\left({ }^{\circ} \mathrm{C}\right)\end{array}$ & $\begin{array}{l}\text { Light intensity } \\
\text { (lux) }\end{array}$ & $\begin{array}{l}\text { Shoot density } \\
\left(\mathrm{m}^{-2}\right)\end{array}$ & $\begin{array}{c}\text { Biomass } \\
\left(\mathrm{g} \text { dry } \mathrm{wt}^{-2}\right)\end{array}$ & LAI & $\begin{array}{c}\mathrm{U} \\
\left(\mathrm{m} \mathrm{s}^{-1}\right)\end{array}$ & $\begin{array}{c}\text { TKE } \\
\left(10^{-6} \mathrm{~m}^{2} \mathrm{~s}^{-2}\right)\end{array}$ & $\begin{array}{l}\text { Re Stress } \\
\quad(\mathrm{Pa})\end{array}$ \\
\hline \multicolumn{10}{|l|}{ September } \\
\hline Sta Maria & 1 & $26.6( \pm 0.16)$ & $6644( \pm 841)$ & $582( \pm 68)$ & 515.48 & 1.23 & $0.012\left( \pm 3 \quad 10^{-4}\right)$ & $2129( \pm 20)$ & $-285( \pm 7)$ \\
\hline Sta Maria & 2 & $26.5( \pm 0.16)$ & $6644( \pm 841)$ & $778( \pm 87)$ & 419.57 & 1.22 & & & \\
\hline St Elm & 1 & $26.8( \pm 0.07)$ & $5442( \pm 414)$ & $368( \pm 90)$ & 465.75 & 0.69 & $0.013\left( \pm 510^{-4}\right)$ & $1883( \pm 11)$ & $158( \pm 2)$ \\
\hline St Elm & 2 & $26.8( \pm 0.08)$ & $5442( \pm 414)$ & $456( \pm 56)$ & 647.37 & 1.39 & $0.012\left( \pm 510^{-4}\right)$ & $1930( \pm 13)$ & $-91( \pm 2)$ \\
\hline Magalluf & 1 & $26.4( \pm 0.20)$ & $6711( \pm 1097)$ & $580( \pm 51)$ & 606.02 & 1.35 & $0.018\left( \pm 610^{-4}\right)$ & $2084( \pm 23)$ & $-50( \pm 2)$ \\
\hline \multicolumn{10}{|l|}{ June } \\
\hline Son Veri Nou & 1 & $23.4( \pm 0.33)$ & $8230( \pm 1525)$ & $607( \pm 107)$ & 714.85 & 1.9 & $0.007\left( \pm 310^{-4}\right)$ & $279( \pm 8)$ & $-0.46( \pm 2)$ \\
\hline Son Veri Nou & 2 & $23.4( \pm 0.30)$ & $8230( \pm 1525)$ & $577( \pm 102)$ & 417.34 & 1.1 & & & \\
\hline Cala Blava & 1 & $23.2( \pm 0.35)$ & $7056( \pm 842)$ & $624( \pm 104)$ & 1012.86 & 2.9 & $0.006\left( \pm 210^{-4}\right)$ & $238( \pm 10)$ & $-14( \pm 1)$ \\
\hline Cala Blava & 2 & $23.2( \pm 0.35)$ & $7056( \pm 842$ & $537( \pm 157)$ & 648.51 & 2.47 & $0.007\left( \pm 310^{-4}\right)$ & $254( \pm 11)$ & $10( \pm 1)$ \\
\hline Magalluf & 3 & $23.4( \pm 0.24)$ & $8752( \pm 2348)$ & $467( \pm 144)$ & 712.99 & 2.76 & $0.004\left( \pm 210^{-4}\right)$ & $748( \pm 10)$ & $-17( \pm 1)$ \\
\hline
\end{tabular}

\section{Methods}

We examined $\mathrm{pH}$ and $\mathrm{O}_{2}$ fluctuations in six $P$. oceanica meadows off the coast of Mallorca (W. Mediterranean, Spain; Fig. 1). Measurements were made in September (723 September 2011), just before leaf shedding and removal by autumn storms and in June (5-15 June 2012), at the peak of $P$. oceanica production (Frankingnoulle and Disteche, 1984). Three meadows were visited in September and four in June with one meadow (Magalluf) sampled in both seasons (Fig. 1). We chose shallow (5-12 $\mathrm{m}$ depth) meadows with a wide range of shoot densities (Table 1) to evaluate the influence of structural parameters. At each meadow we carried out measurements in two stands of relatively dense $P$. oceanica separated by at least $20 \mathrm{~m}$ of meadow and sandy patches. Additionally, in September we took measurements in the centre of one bare sandy patch (2-20 m diameter) per station.

\subsection{Carbonate system and oxygen measurements}

A multiparametric sensor (Hydrolab DS5X) was deployed within the seagrass canopy $0.1 \mathrm{~m}$ above the bottom at each site and recorded local $\mathrm{pH}_{\mathrm{NBS}}, \mathrm{O}_{2}$, salinity and temperature every $15 \mathrm{~min}$. A central cleaning system was attached to avoid fouling of the sensors. The oxygen sensors (Hach LDO $^{\circledR}$ Sensor) were calibrated with the water-saturated air method and the $\mathrm{pH}$ sensors (with Integrated Reference) with a two-point calibration (before and after each deployment) using NBS standard buffers of 7.00 and $10.00 \mathrm{pH}_{\mathrm{NBS}}$. During the September campaign we were unable to obtain oxygen data from one vegetated and one bare site due to instrument malfunction. During the June deployments, one instrument was flooded, leading to the loss of those data. Total alkalinity samples were taken at the bottom and surface before and after each deployment, fixed with $20 \mu \mathrm{L} \mathrm{HgCl}_{2}$ and measured within 3 months (using the Metrohm Titrando 808 after SOP3b of Dickson et al., 2007). Light conditions were registered with a HOBO data logger $\left(\right.$ Pendant $^{\circledR}$, Onset Computer Corporation) attached to the Hydrolab. Additionally, we obtained irradiance data $\left(\mathrm{W} \mathrm{m}^{-2}\right)$ from the meteorological station at Ses Salines (located at the Southeastern point of Mallorca) as an additional measure of the light conditions on the surface during our campaigns. The maximum, minimum, and average $\mathrm{pH}_{\mathrm{NBS}}$ were extracted for each $24 \mathrm{~h}$ period from data obtained during the full deployment. Since not all measurements covered $72 \mathrm{~h}$, we calculated mean $\mathrm{pH}_{\mathrm{NBS}}$ over $24 \mathrm{~h}$ from $2.15 \mathrm{pm}$ to the same time the next day for the first two deployment days, while from 11:15 to the same time for the third deployment day. Consequently, there is a $3 \mathrm{~h}$ overlap for the average $\mathrm{pH}_{\mathrm{NBS}}$ on day two and three. The range of the $\mathrm{pH}$ fluctuation was calculated as the difference from the lowest or highest $\mathrm{pH}_{\mathrm{NBS}}$ to the maximum or minimum $\mathrm{pH}_{\mathrm{NBS}}$ during the next day. Additional parameters of the carbonate system were calculated from the in situ $\mathrm{pH}_{\mathrm{NBS}}$, temperature, and salinity data, and the discrete total alkalinity samples, which were linearly interpolated across the deployment time. DIC and the saturation state of aragonite $\left(\Omega_{\mathrm{Ar}}\right)$ were calculated using CO2SYS excel programme (Pierrot et al., 2006) with the K1 and K2 constants from Mehrbach et al. (1973), as modified by Dickson and Millero (1987), and the $\mathrm{K}_{\mathrm{HSO} 4}$ constant from Dickson (1990).

\subsection{Hydrodynamic regime}

At every site, water velocity in 3 dimensions was measured during bursts programmed in time (every $15 \mathrm{~min}$; in 
sync with the Hydrolab measurements) at $32 \mathrm{~Hz}$, with a total of 5000 samples using Acoustic Doppler Velocimeters (Nortek, Vector). Measurements were taken just above the canopy level, at $1.2 \mathrm{~m}$ above the bottom. Absolute water velocity $\left(u\right.$ in $\left.\mathrm{m} \mathrm{s}^{-1}\right)$ was calculated for each site (Table 1) from the measurements in the $\mathrm{x}$ and $\mathrm{y}$ direction (horizontal plane); as well as Turbulent Kinetic Energy (TKE, as $0.5 *\left(u^{\bar{\prime} 2}+\bar{v}^{\bar{\prime} 2}+w^{-\prime 2}\right)$ in $\left.\mathrm{m}^{2} \mathrm{~s}^{-2}\right)$, and Reynolds Stress (as $\rho\left(u^{\prime^{-}} w^{\prime}\right)$ in $\mathrm{Pa}$ or $\left.\mathrm{N} \mathrm{m}^{-2}\right)$.

\subsection{Meadow characterisation}

At each sampling location we characterised the structural parameters of the meadow. Shoot density was estimated in eight replicate $0.0625 \mathrm{~m}^{2}$ quadrats in September and six replicate $0.05 \mathrm{~m}^{2}$ quadrats in June. To determine biomass and Leaf Area Index (LAI), twelve shoots were randomly collected at each sampling site. The length and width of all leaves were measured, and the mean total leaf area per shoot multiplied by the shoot density to obtain the LAI $\left(\mathrm{m}^{2}\right.$ leaves $\left.\mathrm{m}^{-2}\right)$. All leaves were dried at $60^{\circ} \mathrm{C}$ for $48 \mathrm{~h}$ and the aboveground dry weight $\left(\mathrm{g} \mathrm{m}^{-2}\right)$ was determined as the product of the average shoot weight and density.

To obtain the total leaf carbonate load, dried shoots were burned at $550{ }^{\circ} \mathrm{C}$ for $4 \mathrm{~h}$ and weighed to determine organic matter $(\mathrm{OM})$ content. Shoots were then combusted at $1000^{\circ} \mathrm{C}$ for $2 \mathrm{~h}$ and weighed again. The weight lost between 550 and $1000^{\circ} \mathrm{C}$ represents the carbonate load (Smith and Atkinson 1984). We assume that the bulk of the carbonate can be attributed to the associated epiphytes on the leaf surface. Internally precipitated inorganic carbonate is also included with this method, although internal content of carbonates in the leaves should be negligible (Gacia et al., 2003).

\subsection{Statistical analyses}

We tested the effect of structural parameters of the meadow on oxygen concentrations $\left(\mathrm{mg} \mathrm{L}^{-1}\right)$ and the carbonate system $\left(\mathrm{pH}_{\mathrm{NBS}}\right.$ and $\left.\Omega_{\mathrm{Ar}}\right)$ with a Generalized Linear Mixed Model (GLMM) in R (lme4 package; R Development Core Team 2011) using site (variation of daily mean, max, min and range per day) as a random factor. We tested the effects of hydrodynamics on $\Omega_{\mathrm{Ar}}$ using Generalized Linear Models (GLM) in R since the distinction between seasons meant we were left with too few data points to evaluate a random effect. We used the same approach (GLM) for the analysis of the effect of $\Omega_{\mathrm{Ar}}$ (max, min, mean, range) on the carbonate load of the leaves. We evaluated which set of parameters (structural, hydrodynamic, metabolism) was the best predictor for $\Omega_{\mathrm{Ar}}$ in the meadow by model selection using Akaike's Information Criterion (AIC). As our several structural and hydrodynamic parameters are auto-correlated, we performed a Principal Component Analysis (PCA) in R to obtain 1 principal component for the structural and 1 for the hydrodynamic set explaining most of the variation which we used as input, together with the range of oxygen concentrations for our GLMM (prediction $\Omega_{\mathrm{Ar}}$ ) or GLM (prediction $\mathrm{CaCO}_{3}$ ).

In figures portraying correlations with mean, max, min, and range $\mathrm{pH}$ and $\Omega_{\mathrm{Ar}}$, linear regressions are based on repetitive measurements and significance should be inferred from the GLMM models.

\section{Results}

Cumulative light ( $\mathrm{W} \mathrm{m}^{-2} \mathrm{day}^{-1}$ ) was $54622 \pm 2691$ (SE) in September and $74000 \pm 1615$ (SE) in June. Like the average daily light intensity, $402 \pm 21$ (SE) and $477 \pm 10$ (SE) $\mathrm{W} \mathrm{m}^{-2}$ respectively this represents a significant difference (Students $t$ test, $p<0.01$ ) between seasons. Salinity was on average $40 \pm 0.10 \mathrm{SD}$ ppt in September and $39 \pm 0.92 \mathrm{ppt}$ in June. See Table 1 for specification of the environmental parameters of the sites.

Oxygen concentrations in the water column followed the diurnal cycle of daylight and photosynthetic activity of the plants with highest concentrations observed in the afternoon and the lowest around sunrise (Fig. 2). In September, oxygen concentrations were overall lower and typically ranged from 6.04 to $7.23 \mathrm{mg} \mathrm{O}_{2} \mathrm{~L}^{-1}$ compared to those in June (Table 2, S1). The highest value measured in September was $8.02 \mathrm{mg} \mathrm{O}_{2} \mathrm{~L}^{-1}$ and the lowest $4.18 \mathrm{mg} \mathrm{O}_{2} \mathrm{~L}^{-1}$ $(111 \%$ and $66 \%$ saturation, respectively, mean water temperature $26.5 \pm 0.23 \mathrm{SD}{ }^{\circ} \mathrm{C}$ ). In June, the range was larger and the overall values higher with a mean range from 7.62 to $9.94 \mathrm{mg} \mathrm{O}_{2} \mathrm{~L}^{-1}$. The highest value measured in June was $11.7 \mathrm{mg} \mathrm{O}_{2} \mathrm{~L}^{-1}$ and the lowest $5.29 \mathrm{mg} \mathrm{O}_{2} \mathrm{~L}^{-1}(161 \%$ and $77 \%$ saturation, respectively, mean water temperature $\left.23.4 \pm 0.18 \mathrm{SD}{ }^{\circ} \mathrm{C}\right)$.

We observed clear diurnal patterns in $\mathrm{pH}_{\mathrm{NBS}}$, following those of oxygen (Fig. 2a and b, Table 2). Oxygen production by photosynthesis, or metabolic activity of the plants during the day directly influenced the carbonate system in the meadow, as there was a strong correlation between $\mathrm{O}_{2}$ (in $\mu \mathrm{mol} \mathrm{kg}{ }^{-1}$ ) and DIC (in $\mu \mathrm{mol} \mathrm{kg}{ }^{-1}$ ) in the canopy with an average daytime relationship for all the experimental sites of $-0.97 \mu \mathrm{mol} \mathrm{DIC} / \mu \mathrm{mol} \mathrm{O} \mathrm{O}_{2}$ in September and $-0.96 \mu \mathrm{mol}$ $\mathrm{DIC} / \mu \mathrm{mol} \mathrm{O}_{2}$ in June (average mean $\mathrm{r}^{2}$ of 0.90 ). During the nighttime, when respiration is dominant, this relationship was $-1.13 \mu \mathrm{mol} \mathrm{DIC/ \mu mol} \mathrm{O}_{2}$ in September and $-0.92 \mu \mathrm{mol}$ $\mathrm{DIC} / \mu \mathrm{mol} \mathrm{O} \mathrm{O}_{2}$ in June (average mean $r^{2}$ of 0.88 ). The mean $\mathrm{pH}_{\mathrm{NBS}}$ for all sites was similar in September $(8.03 \pm 0.02)$ and June $(8.06 \pm 0.22 ; t=-0.95, p=0.36)$. However, the maximum observed $\mathrm{pH}_{\mathrm{NBS}}$ during the daily cycles was lower in September $(8.09 \pm 0.02)$ than in June $(8.19 \pm 0.09 ; t=$ $-3.44, p<0.01)$, driven by the higher productivity of the plants, while the minimum $\mathrm{pH}_{\mathrm{NBS}}$ was the same in both seasons (7.97 \pm 0.03 and $7.97 \pm 0.03$ in September and June, respectively, $t=0.08, p=0.93$ ). See Table $\mathrm{S} 1$ for an overview of all maximum and minimum values. Consequently, the 

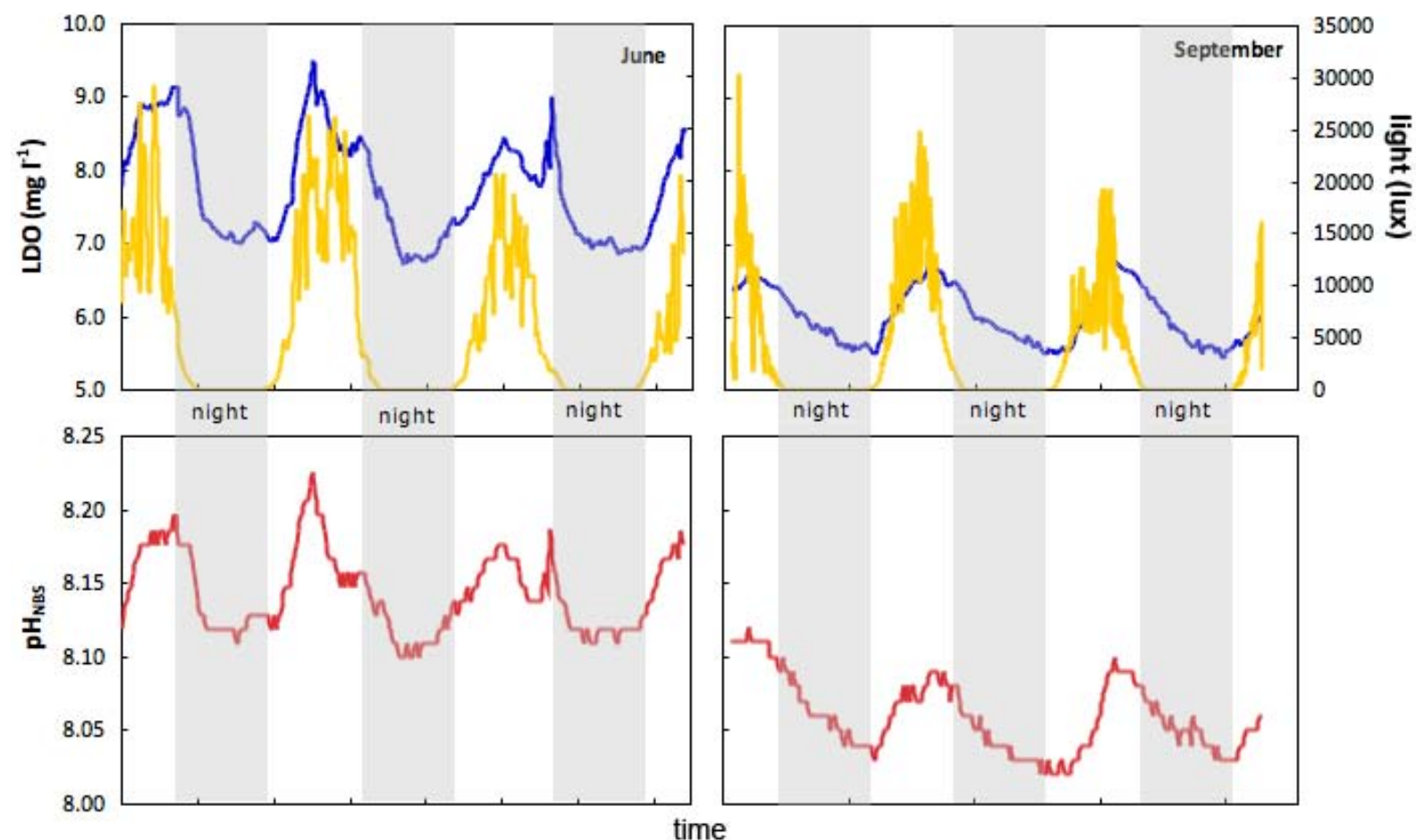

Fig. 2. Diurnal profiles of light levels (lux) and of oxygen concentration ( $\mathrm{mg} \mathrm{L}^{-1}$; upper panels) and $\mathrm{pH}$ (lower panels) in the canopy during the June (left panels) and September campaigns (right panels) in Magalluf.

mean range in $\mathrm{pH}$ was smaller in September $(0.08 \pm 0.01)$ than in June $(0.16 \pm 0.01 ; t=-4.41, p=0.001)$. The smallest diel ranges of $0.05 \mathrm{pH}$ units were observed in the meadows of St. Maria and St. Elm in September and maximum diel ranges of $0.24 \mathrm{pH}$ units were observed in the Bay of Palma (Cala Blava) in June (Table 2).

Measurements of $\mathrm{pH}_{\mathrm{NBS}}$ and oxygen in bare areas adjacent (max. $10 \mathrm{~m}$ from the nearest edge) to the seagrass meadows ( $n=3$; September campaign only) demonstrated clear diurnal patterns (data not shown) similar to those found in the seagrass canopy, indicating a large spatial footprint for seagrass metabolic effects on $\mathrm{O}_{2}$ and $\mathrm{pH}$. Oxygen ranged from 5.72 to $6.95 \mathrm{mg} \mathrm{O}_{2} \mathrm{~L}^{-1}$, which is comparable to the values measured inside the meadow during September. Mean $\mathrm{pH}_{\mathrm{NBS}}$ was $8.02 \pm 0.04 \mathrm{SD}$, ranging diurnally between 0.06 to 0.21 units, significantly lower than the mean $\mathrm{pH}_{\mathrm{NBS}}$ in the vegetated sites $(8.03 \pm 0.02, t=13.98, p<0.001)$.

The biomass of seagrass at the sites affected the mean, maximum and minimum oxygen concentrations within the canopy (GLMM; $p<0.05$ ) while the leaf surface available for photosynthesis (LAI) affected all measured oxygen concentrations (mean, max, min and range, Table S3, Fig. S2; $p<0.01)$. We found strong relationships between oxygen within the canopy and $\mathrm{pH}$ suggesting photosynthetic rates and metabolism are important drivers of the carbonate system within the meadow (Fig. S4). Oxygen concentration ( $\max$ and mean) was correlated to the maximum $\mathrm{pH}_{\mathrm{NBS}}$ measured during the deployments $\left(r^{2}=0.54, F=10.68\right.$, $p<0.01$ with slope $a=0.03$ and $r^{2}=0.72, F=23.28$, $p<0.001$ with slope $a=0.08$ for max and mean, respectively). The range of $\mathrm{pH}$ measurements was correlated to oxygen concentrations (in $\mathrm{mg} \mathrm{L}^{-1}$ ) through production of oxygen and carbon consumption during photosynthesis by the metabolic activity of the plants ( $\max$ and mean; $r^{2}=$ $0.87, F=61.86, p<0.0001$ and $r^{2}=0.67, F=18.29, p<$ 0.01 , respectively), probably as a direct result of the higher maximum $\mathrm{pH}_{\mathrm{NBS}}$. The range of $\Omega_{\mathrm{Ar}}$ was correlated to oxygen concentrations (maximum and mean $\mathrm{O}_{2} ; r^{2}=0.70 \mathrm{~F}=$ $20.61, p<0.01$ and $r^{2}=0.65, F=16.44, p<0.05$, respectively), but the maximum saturation state in the meadow was not significantly correlated ( $F=4.71, p=0.06$ ) to the mean oxygen concentration.

LAI emerged as the most consistent driver of $\mathrm{pH}$ variability (Table 3; Fig. 3). The observed differences in mean $\mathrm{pH}_{\mathrm{NBS}}$ (Table 2) and $\mathrm{pH}$ fluctuations (max and range) within seagrass canopies could be attributed to differences in LAI between meadows, while they could not be linked to density or biomass (Table 3), while the minimum $\mathrm{pH}_{\mathrm{NBS}}$ was independent of structural meadow parameters (Table 3). We used the intercept of the linear regression between LAI and mean $\mathrm{pH}\left(\mathrm{pH}=0.04 \mathrm{LAI}+7.97, r^{2}=0.31\right.$; Fig. 3$)$ as a hypothetical value for a scenario without vegetation present in the area $(\mathrm{LAI}=0)$. Compared to this hypothetical value, the assessed sites elevated the $\mathrm{pH}$ between 53 and $100 \%$ of the time, with 
Table 2. Biogeochemical parameters of the carbonate system (mean and range $\mathrm{pH}_{\mathrm{NBS}}$ measured as well as the estimated $\%$ of time the $\mathrm{pH}$ was maintained above the hypothetical threshold where no vegetation would be present $(\mathrm{LAI}=0) ; p \mathrm{CO}_{2}$, DIC and $\Omega_{\mathrm{Ar}}$ calculated with the excel version of CO2SYS), oxygen concentration in the canopy $\left(\mathrm{mg} \mathrm{L}^{-1}\right)$ and $\mathrm{CaCO}_{3}\left(\mathrm{~m}^{-2}\right)$ content of seagrass leaves in the meadows.

\begin{tabular}{|c|c|c|c|c|c|c|c|}
\hline Station & Plot & $\begin{array}{c}\mathrm{CaCO}_{3} \\
\left(\mathrm{~m}^{-2}\right)\end{array}$ & $\begin{array}{l}\text { Mean } \mathrm{O}_{2} \\
\left(\mathrm{mg} \mathrm{L}^{-1}\right)\end{array}$ & $\begin{array}{l}\text { Range } \mathrm{O}_{2} \\
\left(\mathrm{mg} \mathrm{L}^{-\mathbf{1}}\right)\end{array}$ & Mean $\mathrm{pH}$ & $\begin{array}{c}\% \text { time over } \\
\text { unvegetated } \\
\mathrm{pH}\end{array}$ & pH Range \\
\hline Sta Maria & 1 & 51.72 & 5.81 & 3.45 & 7.99 & 66 & 0.11 \\
\hline Sta Maria & 2 & 45.41 & 5.84 & 2.78 & 8.00 & 84 & 0.11 \\
\hline St Elm & 1 & 35.70 & 6.12 & 1.51 & 8.02 & 100 & 0.06 \\
\hline St Elm & 2 & 54.17 & & & 8.06 & 100 & 0.10 \\
\hline Magalluf & 1 & 88.05 & 6.02 & 1.34 & 8.06 & 100 & 0.06 \\
\hline Magalluf & 2 & 94.44 & 6.41 & 2.30 & 8.06 & 100 & 0.09 \\
\hline Son Veri Nou & 1 & 113.46 & 7.44 & 2.75 & 8.03 & 89 & 0.17 \\
\hline Son Veri Nou & 2 & 83.48 & 7.19 & 2.99 & 7.99 & 67 & 0.15 \\
\hline Cala Blava & 1 & & 7.70 & 6.41 & 7.98 & 53 & 0.23 \\
\hline Cala Blava & 2 & 123.97 & 7.68 & 5.53 & 8.02 & 89 & 0.24 \\
\hline Magalluf & 3 & 75.15 & 7.70 & 2.74 & 8.14 & 100 & 0.13 \\
\hline Magalluf & 4 & 68.09 & & & & & \\
\hline Portals & 1 & 73.68 & 7.87 & 4.72 & 8.14 & 100 & 0.17 \\
\hline Portals & 2 & 58.26 & 7.77 & 4.33 & 8.14 & 100 & 0.17 \\
\hline station & Plot & $p \mathrm{CO}_{2}$ mean & $p \mathrm{CO}_{2}$ range & mean DIC & range DIC & mean $\Omega_{\mathrm{Ar}}$ & range $\Omega_{\mathrm{Ar}}$ \\
\hline Sta Maria & 1 & 714.01 & 381.32 & 2237.40 & 120.40 & 2.84 & 1.07 \\
\hline Sta Maria & 2 & 685.26 & 257.01 & 2227.95 & 78.19 & 2.93 & 0.68 \\
\hline St Elm & 1 & 655.27 & 119.20 & 2204.51 & 63.16 & 2.99 & 0.45 \\
\hline St Elm & 2 & 586.76 & 202.39 & 2180.18 & 79.32 & 3.23 & 0.84 \\
\hline Magalluf & 1 & 582.69 & 105.46 & 2194.53 & 45.66 & 3.22 & 0.45 \\
\hline Magalluf & 2 & 583.60 & 155.81 & 2194.66 & 62.51 & 3.23 & 0.65 \\
\hline Son Veri Nou & 1 & 628.62 & 452.32 & 2247.03 & 154.70 & 2.81 & 1.57 \\
\hline Son Veri Nou & 2 & 704.35 & 286.02 & 2272.93 & 78.13 & 2.58 & 0.75 \\
\hline Cala Blava & 1 & 714.48 & 507.65 & 2266.70 & 147.30 & 2.54 & 1.38 \\
\hline Cala Blava & 2 & 645.85 & 490.79 & 2247.51 & 170.96 & 2.73 & 1.67 \\
\hline Magalluf & 3 & 462.70 & 155.98 & 2183.75 & 86.28 & 3.43 & 0.81 \\
\hline Magalluf & 4 & 463.08 & 281.34 & 2174.50 & 136.76 & & \\
\hline Portals & 1 & 471.85 & 265.46 & 2182.80 & 130.77 & 3.45 & 1.35 \\
\hline Portals & 2 & 714.01 & 381.32 & 2237.40 & 120.40 & 3.41 & 1.29 \\
\hline
\end{tabular}

an average of $88 \pm 16$ (SD) \% of the time above this value (Table 2). For $\Omega_{\text {Ar }}$ the maximum and range were correlated with LAI, while biomass did influence the range significantly as well (Table 3, Fig. 4).

\subsection{Hydrodynamics}

Biomass and density did not have significant effects on measured hydrodynamics (water flow, TKE and Reynolds stress) while LAI affected the flow of water through the meadow as well as the TKE $(t=-3.089, p<0.05$ and $t=-3.25$, $p<0.01$, respectively). Since water velocity was different between June and September $(t=-5.61, p<0.001)$, we separated the analyses of the effect of hydrodynamics on the carbonate system by season (Fig. 5, Table 4). In September, no significant effect of water velocity or mixing on the carbonate system was found. Vertical mixing (as TKE) affected the mean $(t=9.733, p<0.001)$ and minimum $(t=4.255$, $p<0.05) \Omega_{\mathrm{Ar}}$ positively, raising the saturation state with higher mixing intensities. A higher absolute water velocity lowered the mean $\Omega_{\mathrm{Ar}}$ in June $(t=-3.772, p<0.05)$.

$\Omega_{\mathrm{Ar}}$ (mean, max, min and range) does not significantly correlate with the harvested $\mathrm{CaCO}_{3}$ on the leaf surfaces (Table 5) even though there is a positive trend discernable with the maximum and range of $\Omega_{\mathrm{Ar}}$ within the canopy and $\mathrm{CaCO}_{3}$.

\subsection{Model selection}

The best models predicting minimum $\Omega_{\mathrm{Ar}}$ included meadow metabolic activity (as range $\mathrm{O}_{2}$ concentration, Table 6), however the mean, max and min $\Omega_{\mathrm{Ar}}$ were best determined by models with only hydrodynamic components (Table 6 ). The best model to predict $\mathrm{CaCO}_{3}$ content per $\mathrm{m}^{2}$ of the leaves included all factors; structural parameters, hydrodynamics and the range of oxygen concentration within the canopy 
Table 3. Results from Generalized Linear Mixed Models (lme4 package in R) with Gaussian distribution, and link identity with site as a random effect (repeated measures) testing the effect of structural parameters on the mean, max, min and range of $\mathrm{pH}$ and $\Omega_{\mathrm{Ar}}$. Where no results are given the no-slope model explained more variation.

\begin{tabular}{cl|cc|cc|cc}
\hline & & \multicolumn{2}{|c|}{ Shoot density } & \multicolumn{2}{c|}{ Biomass } & \multicolumn{2}{c}{ LAI } \\
& & $\chi^{2}$ & $p$ & $\chi^{2}$ & $p$ & $\chi^{2}$ & $p$ \\
\hline $\mathrm{pH}$ & Mean & 1.826 & 0.18 & 1.0069 & 0.32 & 5.293 & $<0.05^{*}$ \\
& Max & 0.9655 & 0.33 & 3.6949 & 0.05 & 15.831 & $<0.001^{* * *}$ \\
& Min & 2.453 & 0.12 & 0.1176 & 0.73 & 1.456 & 0.23 \\
& range & 0.0214 & 0.88 & 3.5856 & 0.06 & 9.2126 & $<0.01^{* *}$ \\
\hline \multirow{2}{*}{$\Omega \mathrm{Ar}$} & Mean & 7.441 & 0.23 & 7.723 & 0.73 & 12.287 & 0.33 \\
& Max & 1.0926 & 0.30 & 2.2928 & 0.13 & 8.7876 & $<0.01^{* *}$ \\
& Min & 1.8925 & 0.17 & - & - & - & - \\
& range & - & - & 1.0926 & 0.04 & 14.2 & $<0.001^{* * *}$ \\
\hline
\end{tabular}

Significance levels: ${ }^{*} p<0.05,{ }^{* *} p<0.01,{ }^{* * *} p<0.001$

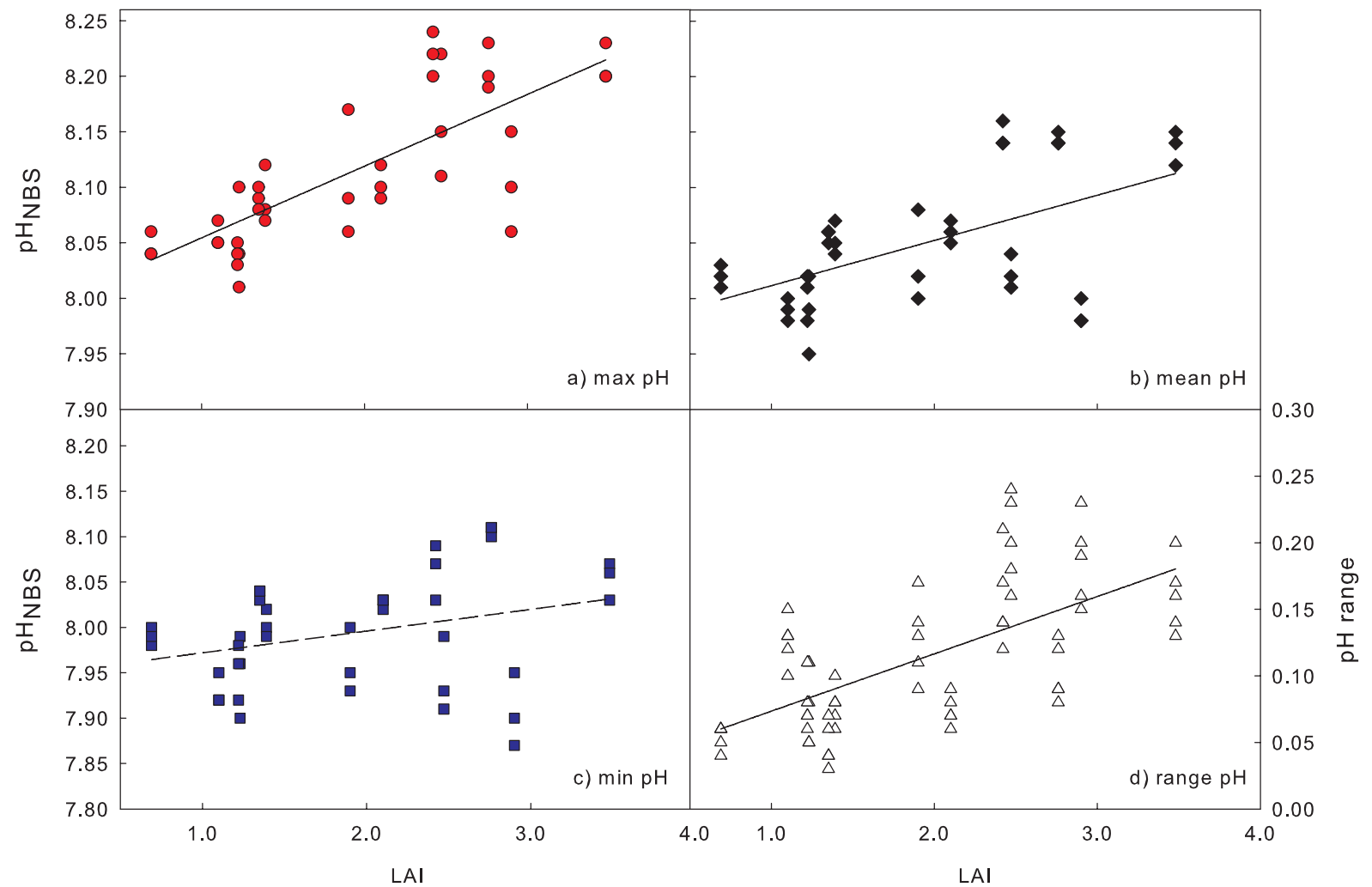

Fig. 3. The relationships between leaf area index (LAI) and (a) max, (b) mean, (c) min $\mathrm{pH}$ and (d) $\mathrm{pH}$ range. Non-significant relationships are dotted lines. Linear regressions are described for maximum $\mathrm{pH}$ (red circles) as $0.06 \mathrm{LAI}+7.99\left(r^{2}=0.60\right)$, Mean $\mathrm{pH}$ (black diamonds) by $0.04 \mathrm{LAI}+7.97,\left(r^{2}=0.31\right)$, Minimum $\mathrm{pH}$ are blue squares while the range of $\mathrm{pH}$ (right $y$ axis) are white triangles with linear regression $0.04 \mathrm{LAI}+0.03\left(r^{2}=0.42\right)$.

(Table 7). The second best model with only a slightly higher score, explains $\mathrm{CaCO}_{3}$ content through metabolic activity only.

\section{Discussion}

The island of Mallorca lacks rivers and surface runoff, although $\mathrm{CO}_{2}$ from soil respiration can be delivered to coastal waters through groundwater inputs (Basterretxea et al., 2010). However, salinity maintains open-sea Mediterranean water properties, thereby pointing to a clear dominance 


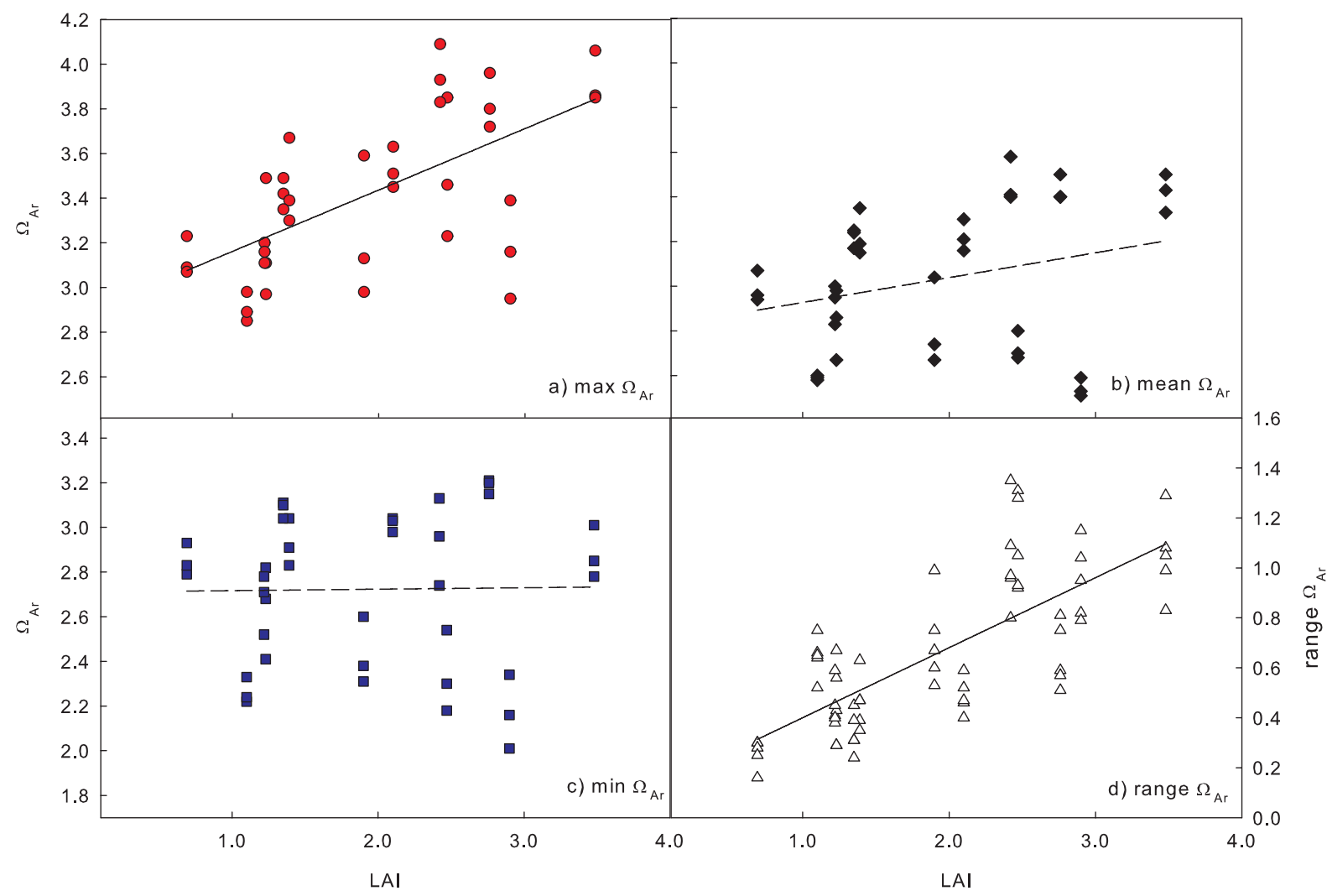

Fig. 4. The relationships between leaf area index (LAI) and (a) max, (b) mean, (c) min $\Omega_{\mathrm{Ar}}$ and the (d) range of $\Omega_{\mathrm{Ar}}$. Non-significant relationships are dotted lines. The linear regression for maximum $\Omega_{\mathrm{Ar}}$ (red circles) is $0.28 \mathrm{LAI}+2.87\left(r^{2}=0.40\right)$. Mean $\Omega_{\mathrm{Ar}}$ are black diamonds, Minimum $\Omega_{\mathrm{Ar}}$ are blue squares while the range of $\Omega_{\mathrm{Ar}}$ (right $y$ axis) are white triangles with linear regression $0.28 \mathrm{LAI}+0.12$ $\left(r^{2}=0.56\right)$.

Table 4. Results from Generalized Linear Models (glm package in R) with gaussian distribution testing the effect of hydrodynamics on the $\Omega_{\mathrm{Ar}}$.

\begin{tabular}{ll|cc|cc|cc}
\hline & & \multicolumn{2}{|c|}{ TKE } & \multicolumn{2}{c|}{$U$ velocity } & \multicolumn{2}{c}{ Re stress } \\
& & $t$ & $p$ & $t$ & $p$ & $t$ & $p$ \\
\hline \multirow{2}{*}{ September } & Mean & -0.303 & 0.78 & 1.333 & 0.27 & 0.475 & 0.67 \\
& Max & 0.618 & 0.58 & 0.417 & 0.70 & -1.261 & 0.30 \\
& Min & -0.380 & 0.73 & 2.005 & 0.14 & 1.128 & 0.34 \\
& Range & 0.742 & 0.51 & -1.128 & 0.34 & -2.909 & 0.06 \\
\hline \multirow{2}{*}{ June } & Mean & 9.733 & $<0.001^{* * *}$ & -3.772 & $<0.05^{*}$ & -0.289 & 0.79 \\
& Max & 2.162 & 0.10 & -1.511 & 0.21 & 0.721 & 0.51 \\
& Min & 4.255 & $<0.05^{*}$ & -2.110 & 0.10 & -0.723 & 0.51 \\
& Range & -1.804 & 0.15 & 1.220 & 0.289 & 2.452 & 0.07 \\
\hline
\end{tabular}

Significance levels: ${ }^{*} p<0.05,{ }^{* *} p<0.01,{ }^{* * *} p<0.001$

of oceanic forcing on biogeochemical properties, including $\mathrm{pH}$. Island environments with small watersheds have been suggested to be particularly vulnerable to ocean acidification, unless they contain metabolically intense ecosystems (Duarte et al., 2013), such as Posidonia oceanica meadows in Mediterranean islands. We show that the metabolism of $P$. oceanica meadows, which are autotrophic ecosystems, can affect $\mathrm{pH}$ even imposing a range of $\mathrm{pH}$ daily comparable to the predicted range due to ocean acidification over the $21 \mathrm{st}$ Century (Doney et al., 2009). We found highly temporally variable $\mathrm{pH}$ environments in seagrass ecosystems with the magnitude of diurnal $\mathrm{pH}$ variation strongly related to seagrass productivity, with the largest ranges coinciding with the peak in seagrass productivity and directly related to the leaf 

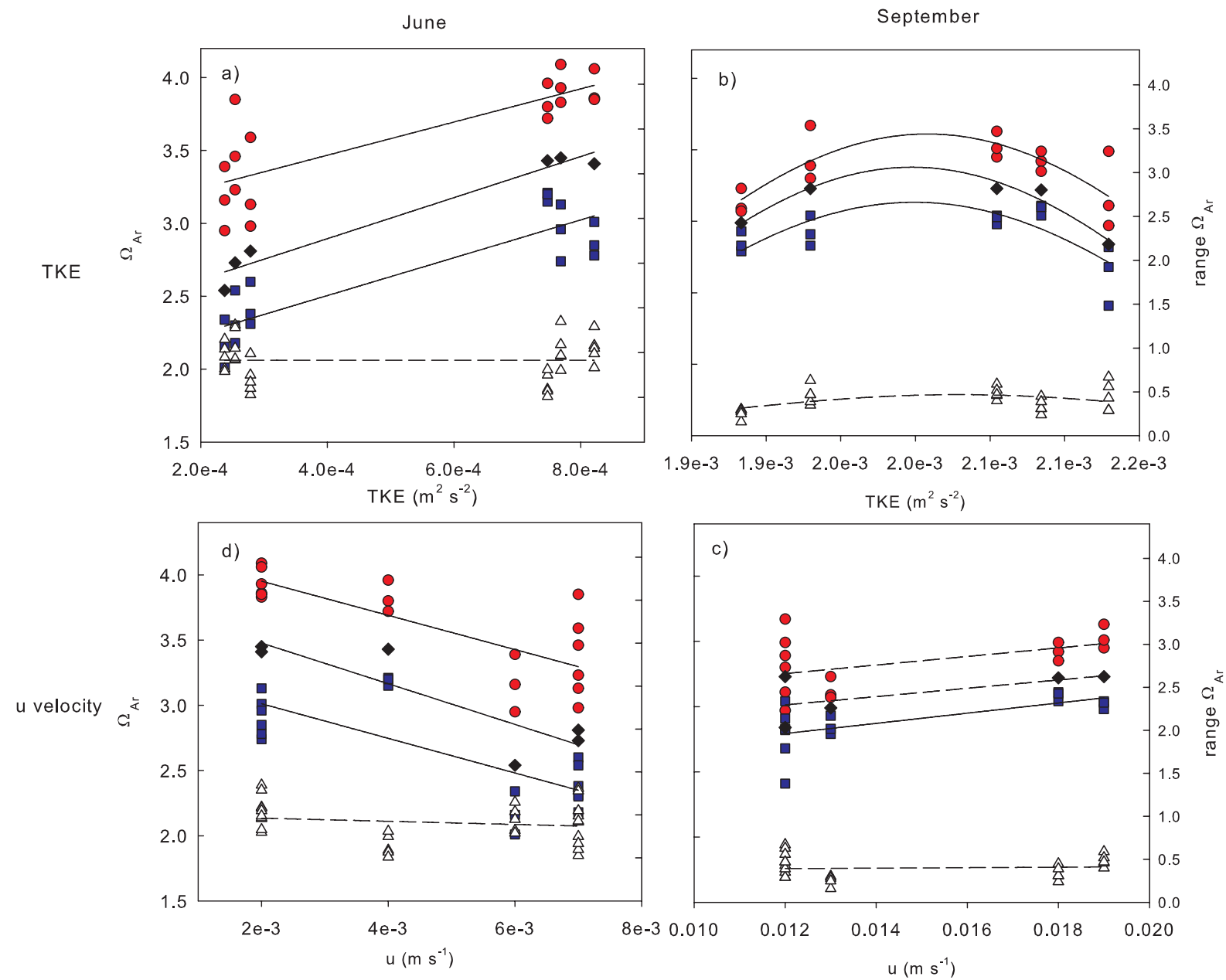

Fig. 5. The relationship between (a), (b) TKE $\left(\mathrm{m}^{2} \mathrm{~s}^{-2}\right)$ and (c), (d) $u\left(\mathrm{~m} \mathrm{~s}^{-1}\right)$ and max, mean, min and the range of $\Omega_{\mathrm{Ar}}$. Nonsignificant relationships are dotted lines. Regressions are linear $(y=a x+b)$, except fo TKE in September, where they are peak models $\left(y=a^{-\sqrt{ }((x-x 0) / b) 2}\right)$ Maximum $\Omega_{\mathrm{Ar}}$ is represented with red circles, Mean $\Omega_{\mathrm{Ar}}$ are black diamonds, Minimum $\Omega_{\mathrm{Ar}}$ are blue squares while the range of $\Omega_{\mathrm{Ar}}$ (right y-axis) are white triangles.

Table 5. Results from Generalized Linear Models (glm package in R) with gaussian distribution testing the effect of saturation of omega aragonite $\left(\Omega_{\mathrm{Ar}}\right.$, predictor) on the $\mathrm{CaCO}_{3}$ load $\left(\mathrm{m}^{-2)}\right.$ on the leaves.

\begin{tabular}{lll}
\hline$\Omega_{\mathrm{Ar}}$ & $t$ & $p$ \\
\hline Mean & -0.830 & 0.43 \\
Max & 1.775 & 0.11 \\
Min & -1.028 & 0.33 \\
Range & 2.064 & 0.07 \\
\hline
\end{tabular}

area index of the plants, which reflects the density of photosynthetic tissues. Leaf area index is not routinely measured, but could be a parameter of interest when evaluating the importance of seagrass meadows on water chemistry.

\subsection{Potential for buffering of the carbonate system in seagrass-dominated coastal ecosystems}

The correlation between oxygen and $\mathrm{pH}$ with an increase in $\max \mathrm{pH}$ and the range of $\Omega_{\mathrm{Ar}}$ with increasing oxygen concentrations suggests that seagrass metabolic activity controls the carbonate system in seagrass canopies. The metabolic signal varies seasonally and the influence on carbonate chemistry is likely to be most pronounced at the peak of seagrass production, in June. Our results highlight the role of hydrodynamic processes in modulating the carbonate system within the canopy. Hydrodynamics control fluxes in and out of the meadow and may modify or dampen the metabolic signal. High community metabolism in seagrass meadows is common, with higher primary productivity rates in tropical meadows as compared to temperate ones (Duarte et al., 2010). The capacity to modify coastal $\mathrm{pH}$ in shallow nearshore water with submerged vegetation is wide-spread, in 
Table 6. Model selection for Generalized Linear Mixed Models (lme4 package in R) predicting $\Omega_{\text {Ar }}$ with Gaussian distribution and site as random effect (repeated measures). Structural and hydrodynamic components are summarized in the principal component from a PCA analysis (in R), explaining 73 and $99 \%$, respectively of the original parameters. For Metabolism we used the range of oxygen concentration $\left(\mathrm{mg} \mathrm{L}^{-1}\right)$ as a proxy. Aikaike's information criterion (AIC) is as less-is-better, the best model value is highlighted in bold.

\begin{tabular}{lrrrr}
\hline Model & $\operatorname{range} \Omega_{\mathrm{Ar}}$ & $\min \Omega_{\mathrm{Ar}}$ & $\max \Omega_{\mathrm{Ar}}$ & $\operatorname{mean} \Omega_{\mathrm{Ar}}^{\dagger}$ \\
\hline structural & 17.74 & 31.51 & 28.93 & 26.95 \\
structural * season & -26.06 & 26.49 & 30.78 & 27.85 \\
structural + season & -27.98 & 26.73 & 30.08 & 27.87 \\
structural (site random) & -13.85 & 13.30 & 28.53 & -3.26 \\
structural + hydrodynamics (site random) & -16.12 & 8.41 & 22.61 & -3.86 \\
structural + hydrodynamics + metabolism (site random) & -49.11 & 13.01 & 27.93 & 3.28 \\
structural + metabolism (site random) & -68.13 & 20.26 & 33.60 & 4.60 \\
metabolism (site random) & $-\mathbf{8 5 . 2 2}$ & 5.80 & 19.44 & -10.34 \\
metabolism + hydrodynamics (site random) & -65.53 & 0.02 & 13.36 & -10.51 \\
Hydrodynamics (site random) & -29.43 & $\mathbf{- 5 . 3 8}$ & $\mathbf{7 . 6 8}$ & $\mathbf{- 1 8 . 0 4}$ \\
\hline
\end{tabular}

$\dagger$ Values in italics are evaluated using a GLM without random factor.

Table 7. Model selection for GLM models predicting $\mathrm{CaCO}_{3} \mathrm{~m}^{-2}$ with gaussian distribution and link identity. Structural and hydrodynamic components are summarized in the principal component from a PCA analysis (in R), explaining 73 and $99 \%$, respectively of the original parameters. For Metabolism we used the range of oxygen concentration $\left(\mathrm{mg} \mathrm{L}^{-1}\right)$ as a proxy. Aikaike's information criterion (AIC) is as less-is-better, the best model value is highlighted in bold.

\begin{tabular}{lr}
\hline Model & AIC \\
\hline structural & 115.88 \\
structural * season & 116.11 \\
structural + season & 118.23 \\
structural + hydrodynamics & 99.79 \\
structural + hydrodynamics + metabolism & $\mathbf{9 2 . 2 9}$ \\
structural + metabolism & 108.62 \\
metabolism & 92.88 \\
metabolism + hydrodynamics & 100.14 \\
\hline
\end{tabular}

areas with seagrass (Buapet et al., 2013; Hofmann et al., 2011; Invers et al., 1997; Semesi 2009; Schmalz and Swanson, 1969) and as well as in macrophyte habitats in general, such as kelps (Delille et al., 2000; Frieder et al., 2012; Hofmann et al., 2011; Menendez et al., 2001; Middelboe and Hansen, 2007), but the magnitude of buffering will depend on both structural and metabolic parameters and hydrodynamic processes of each system while the properties of the emerging canopy of the meadow (e.g. LAI) simultaneously control photosynthetic rates and affect hydrodynamic processes (Gutierrez et al., 2012).

\subsection{Future potential for calcifiers living in the meadow}

The changes in $\mathrm{pH}$ and $\Omega_{A r}$ associated with Posidonia oceanica meadows are sufficiently large to be able to facilitate calcification processes. This effect is driven by struc- tural parameters of the meadow, with LAI being the best predictor, as this affects both metabolic activity and hydrodynamic regimes. LAI is a relative measure including both shoot length and density and therefore takes both seasonality (leaf length) and meadow health (shoot density) into account. LAI is therefore a key parameter that should be measured during experiments. Vertical mixing, related to LAI by its influence on leaf movement in flow, enhances the mean and minimum $\Omega_{\mathrm{Ar}}$ by mixing water from the top of the canopy, where irradiation is at its peak and high productivity is expected, with water from within the canopy. The near-bottom water has a longer residence time, and heterotrophic sediment processes influence the final measured $\mathrm{pH}$ as well as the autotrophic meadow. Therefore enhanced vertical mixing positively influences the carbonate system, measured by the multiparamteric sensor in the lower canopy region. The leafinhabiting calcifying epiphytes might directly benefit from the modification of the carbonate system by the meadow as the positive trend (Table 5) between $\Omega_{\mathrm{Ar}}$ and the carbonate load of the leaves found in this study point to possible beneficial effects. However, the growth of leaf epiphytes is on larger time scales than daily fluctuations and therefore a response in $\mathrm{CaCO}_{3}$ mass might be only visible at the level of seasonal changes in saturation states rather than daily maximum and minimum. The second best model predicting explains $\mathrm{CaCO}_{3}$ load on the leaves included metabolic activity only, with only decimals of difference with the best model including all components (Table 7). Epiphytes living on the leaf surface will experience modifications of $\mathrm{pH}$ and $\Omega_{\mathrm{Ar}}$ much more pronounced than we measured within the meadow, as the diffusive boundary layer limits exchange processes and a gradient between the leaf surface and the water column is developed (Hurd et al., 2011). The present-day meadow might provide refugia for calcifiers by providing a daily window of maximum $\Omega_{\mathrm{Ar}}$ where calcification is more cost efficient. 


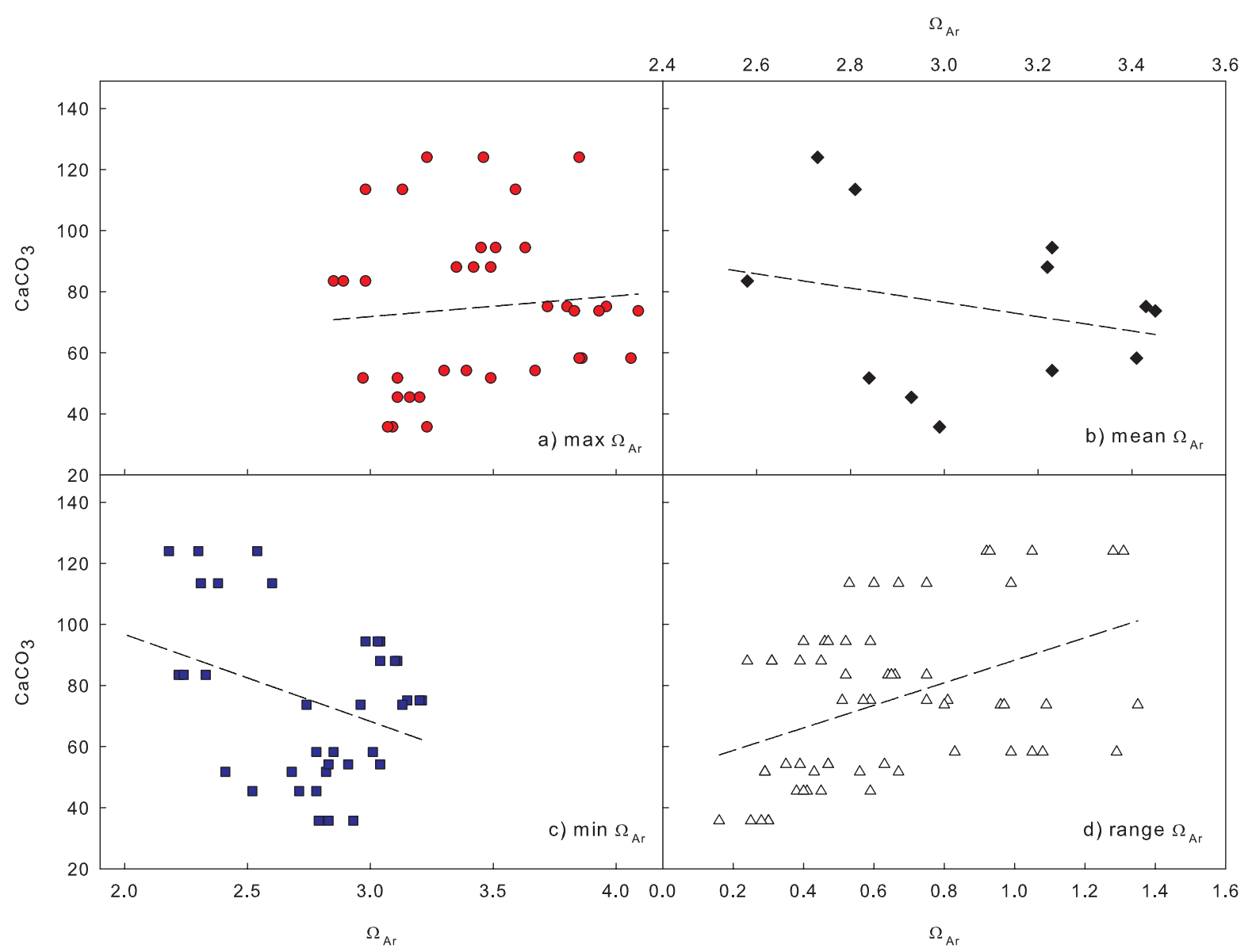

Fig. 6. Calcium carbonate content of the leaves vs. the saturation state of Aragonite $\left(\Omega_{\mathrm{Ar}}\right)$ in the meadow. The linear regression is described as $\mathrm{CaCO}_{3}=20.12 \Omega_{\mathrm{Ar}}-16.48$.

There is, however, concern for the ability of seagrasses to continue to provide this function in the future. Seagrass meadows are declining worldwide (Waycott et al., 2009) and, in the Mediterranean, shoot densities are diminishing at an alarming rate (Marbà and Duarte, 2010). Since the pH modification is directly linked to the structural parameters of the meadow the ability of seagrass meadows to provide beneficial conditions for calcifiers in the Mediterranean and globally is threatened.

Future increased levels of $\mathrm{CO}_{2}$ in the atmosphere and a subsequent increase in dissolved $\mathrm{CO}_{2}$ are predicted to have significant direct effects on aquatic plant communities (Wetzel and Grace, 1983; Edwards, 1995; Short and Neckles, 1999). At present seagrass photosynthesis is frequently limited by DIC availability under natural conditions (Beer 1989; Durako 1993; Madsen et al., 1993; Koch, 1994; Beer and Koch, 1996). Photosynthetic rates (Durako, 1993; Zimmerman et al., 1997) and growth and biomass (Zimmerman et al., 1997) might increase with increasing $\mathrm{CO}_{2}$ concentrations, although long-term evidence for this is lacking (Short and Neckles, 1999). Acclimation following prolonged exposure to elevated $\mathrm{CO}_{2}$ may lead to down-regulation (Durako, 1993; Madsen et al., 1996) or up-regulation (Zimmerman et al., 1997) of photosynthesis. Long-term responses are therefore likely to depend on the degree of physiological and morphological adaptation to increased $\mathrm{CO}_{2}$ (Drake, 1992; Dahlman, 1993; Amthor, 1995). It is therefore difficult to predict how this may affect the ability of seagrass meadows to buffer the $\mathrm{pH}$ environment within their canopies.

Measurements of diurnal $\mathrm{pH}$ cycles in volcanic vent systems of the Mediterranean Sea indicate that the ability of the meadows to modulate $\mathrm{pH}$ will be significant. The maximum diurnal range in a $P$. oceanica meadow in the Ischia $\mathrm{CO}_{2}$ vent system was very large, at $1.0-1.6$ of $\mathrm{pH}$ units at high $p \mathrm{CO}_{2}$ sites (Duarte et al., 2013). These large diurnal fluctuations are probably the result of a combination of high productivity and photosynthesis in shallow DIC-rich meadows and variability produced by stochastic changes in $\mathrm{CO}_{2}$ venting rates and hydrodynamic conditions, but, in any case, the capacity of seagrasses to modulate $\mathrm{pH}$ through their metabolic activity does not appear to be diminished, and is possibly enhanced, under conditions of increased $p \mathrm{CO}_{2}$. 
Even though seagrass productivity might be enhanced in a high- $p \mathrm{CO}_{2}$ world, other stresses associated with global change might play a negative role. Like other seagrasses, $P$. oceanica meadows are highly vulnerable to coastal deterioration and are currently threatened by eutrophication, invasive species, coastal erosion and mechanical impacts (Williams, 2007; Diaz-Almela et al., 2008; Boudouresque et al., 2009). Declines of $P$. oceanica have been reported across the entire Mediterranean basin and it has been estimated that 13-50\% of $P$. oceanica area may have been lost, and that shoot density has declined in the remaining areas, with little scope for recovery, provided the very slow growth of this species (Marbà and Duarte, 1998). Rapid warming of the Mediterranean is enhancing seagrass decline further (Marbà and Duarte, 2010) and will enhance shoot mortality and trigger population decline as critical temperature thresholds are exceeded (Marbà and Duarte, 2010; Jordà et al., 2012).

The predicted global decline of seagrass meadows (Orth et al., 2006; Waycott et al., 2009) may alter the ability of the meadows to modify $\mathrm{pH}$ in the water column, in particular if meadows suffer declines in shoot density and biomass. The mean dry weight of the meadows at the height of their production (in June) is very close, even below, the predicted threshold for autotrophy of $P$. oceanica meadows (694.1 vs. $735.3 \mathrm{~g} \mathrm{DW} \mathrm{m}^{-2}$ in Duarte et al., 2010). The ongoing shoot density decrease of seagrass meadows could bring the meadows around Mallorca closer to the threshold for the functional role of $P$. oceanica meadows as a refuge for calcifying. Organisms associated with seagrass communities will therefore be exposed to lower $\mathrm{pH}$ regimes in the future as $\mathrm{pH}$ decreases through ocean acidification and $\mathrm{pH}$-buffering capacity is lost in declining meadows. Effective conservation of seagrass meadows is not only required to preserve these habitats under threat, but also the role they can play in the future in providing $\mathrm{pH}$ modification at local scales for calcifying organisms.

\section{Supplementary material related to this article is available online at http://www.biogeosciences.net/11/333/ 2014/bg-11-333-2014-supplement.pdf.}

Acknowledgements. We thank A. Orfila of the Marine Technologies, Operational Oceanography and Sustainability Department of IMEDEA for the permission to use the Nortek ADV vectors. This research was funded by projects MedSeA (EU contract number FP7-2010-265103) and project ESTRESX funded by the Spanish ministry of economy and competitivity (ref. CTM2012-32603). IEH was funded by a JAE-DOC fellowship from the Spanish Government. YSO was funded by a Marie Curie IEF from the European Union Seventh Framework Programme (FP7/2007-2013) under grant agreement no. 254297: FP7-PEOPLE-2009-IEF. AS was funded by a fellowship from the Government of the Balearic Islands (Department on Education, Culture and Universities) and the EU
(European Social Fund). LR was funded by a fellowship from the Government of Chile (CONICYT, Becas Chile Programm). J. Howard was funded by a scholarship from the International Master in Marine Biodiversity and Conservation Consortium.

Edited by: J.-P. Gattuso

\section{References}

Amthor, J. S.: Terrestrial higher-plant response to increasing atmospheric $\left(\mathrm{CO}_{2}\right)$ in relation to the global carbon cycle, Glob. Chan. Biol., 1, 243-274, 1995.

Beer, S.: Photosynthesis and photorespiration of marine angiosperms, Aquat. Bot., 34, 153-166, 1989.

Beer, S. and Koch, E. W.: Photosynthesis of marine macroalgae and seagrass in globally changing $\mathrm{CO}_{2}$ environments, Mar. Ecol. Prog. Ser., 141, 199-204, 1996.

Boudouresque, C. F., Bernard, G., Pergent, G., Shili, A., and Verlaque, M.: Regression of Mediterranean seagrasses caused by natural processes and anthropogenic disturbances and stress: a critical review, Bot. Mar., 52, 395-418, 2009.

Buapet, P., Gullström, M., and Björk, M.: Photosynthetic activity of seagrasses and macroalgae in temperate shallow waters can alter seawater $\mathrm{pH}$ and total inorganic carbon content at the scale of a coastal embayment, Mar. Freshw. Res., 64, 1040-1048, doi:10.1071/MF12124, 2013.

Dahlman, R. C.: $\mathrm{CO}_{2}$ and plants: Revisited., Vegetatio, 104/105, 339-355, 1993.

Delille, D., Marty, G., Cansemi-Soullard, M., and Frankignoulle, M.: Influence of subantarctic Macrocystis bed metabolism in diel changes of marine bacterioplankton and $\mathrm{CO}_{2}$ fluxes, J. Plankton Res., 19, 1251-1264, 1997.

Díaz-Almela, E., Marbà, N., Álvarez, E., Santiago, R., Holmer, M., Grau, A., Mirto, S., Danovaro, R., Petrou, A., Argyrou, M., Karakassis, I., and Duarte, C. M.: Benthic input rates predict seagrass (Posidonia oceanica) fish farm-induced decline, Marine Pollution Bulletin, 56, 1332-1342, 2008.

Dickson, A. G., Sabine, C. L., and Christian, J. R.: Guide to best practices for ocean $\mathrm{CO}_{2}$ measurements, PICES Special Publication, 191 pp., 2007.

Drake, B. G.:The impact of rising $\mathrm{CO}_{2}$ on ecosystem production, Water Air Soil Pollut., 64, 25-44, 1992.

Duarte, C. and Chiscano, C.: Seagrass biomass and production: a reassessment, Aquat. Bot., 65, 159-174, 1999.

Duarte, C., Hendriks, I., Moore, T., Olsen, Y., Steckbauer, A., Ramajo, L., Carstensen, J., Trotter, J., and McCulloch, M.: Is Ocean Acidification an Open-Ocean Syndrome? Understanding Anthropogenic Impacts on Seawater pH, Estuaries Coasts, 36, 221-236, 2013.

Duarte, C. M., Marbà, N., Gacia, E., Fourqurean, J. W., Beggins, J., Barrón, C., and Apostolaki, E. T.: Seagrass community metabolism: Assessing the carbon sink capacity of seagrass meadows, Global Biogeochem. Cy., 24, GB4032, doi:10.1029/2010GB003793, 2010.

Edwards, A. J.: Impact of climate change on coral reefs, mangroves and tropical seagrass ecosystems, in: Climate Change: Impact on Coastal Habitation, edited by: Eisma, D., Lewis Publishers, Boca Raton, FL, USA, 209-234, 1995. 
Frankignoulle, M. and Bouquegneau, J. M.: Daily and yearly variations of total inorganic carbon in a productive coastal area, Estuar. Coast. Shelf S., 30, 79-89, 1990.

Frankignoulle, M. and Distèche, A.: $\mathrm{CO}_{2}$ chemistry in the water column above a Posidonia seagrass bed and related air-sea exchanges, Oceanol. Acta, 7, 209-219, 1984.

Frieder, C. A., Nam, S. H., Martz, T. R., and Levin, L. A.: High temporal and spatial variability of dissolved oxygen and $\mathrm{pH}$ in a nearshore California kelp forest, Biogeosciences, 9, 3917-3930, doi:10.5194/bg-9-3917-2012, 2012.

Gacia, E., Duarte, C. M., Marba, N., Terrados, J., Kennedy, H., Fortes, M. D., and Tri, N. H.: Sediment deposition and production in SE-Asia seagrass meadows, Estuar. Coast. Shelf S., 56, 909-919, 2003

Gazeau, F., Duarte, C. M., Gattuso, J.-P., Barrón, C., Navarro, N., Ruíz, S., Prairie, Y. T., Calleja, M., Delille, B., Frankignoulle, M., and Borges, A. V.: Whole-system metabolism and $\mathrm{CO}_{2}$ fluxes in a Mediterranean Bay dominated by seagrass beds (Palma Bay, NW Mediterranean), Biogeosciences Discuss., 1, 755-802, doi:10.5194/bgd-1-755-2004, 2004.

Gazeau, F., Quiblier, C., Jansen, J. M., Gattuso, J.-P., Middelburg, J. J., and Heip, C. H. R.: Impact of elevated $\mathrm{CO}_{2}$ on shellfish calcification, Geophys. Res. Lett., 34, L07603, doi:10.1029/2006GL028554, 2007.

Gutiérrez, J. L., Jones, C. G., Byers, J. E., Arkema, K. K., Berkenbusch, K., Commito, J. A., Duarte, C. M., Hacker, S. D., Lambrinos, J. G., Hendriks, I. E., Hogarth, P. J., Palomo, M. G., and Wild, C.: Physical ecosystem engineers and the functioning of Estuaries Coasts, in: Functioning of Estuaries and Coastal Ecosystems, edited by: Heip, C. H. R., Philippart, C. J. M., and Middelburg, J. J., Treatise on Estuarine and Coastal Science, Elsevier, Academic Press, Waltham, 2012.

Hofmann, G. E., Smith, J. E., Johnson, K. S., Send, U., Levin, L. A., Micheli, F., Paytan, A., Price, N. N., Peterson, B., Takeshita, Y., Matson, P. G., Crook, E. D., Kroeker, K. J., Gambi, M. C., Rivest, E. B., Frieder, C. A., Yu, P. C., and Martz, T. R.: High-Frequency Dynamics of Ocean pH: A Multi-Ecosystem Comparison, PLoS ONE, 6, e28983, doi:10.1371/journal.pone.0028983, 2011.

Hurd, C. L., Cornwall, C. E., Currie, K., Hepburn, C. D., McGraw, C. M., Hunter, K. A., and Boyd, P. W.: Metabolically induced $\mathrm{pH}$ fluctuations by some coastal calcifiers exceed projected 22nd century ocean acidification: a mechanism for differential susceptibility?, Glob. Chan. Biol., 17, 3254-3262, 2011.

Invers, O., Romero, J., and Perez, M.: Effects of $\mathrm{pH}$ on seagrass photosynthesis: a laboratory and field assessment, Aquat. Bot., 59, 185-194, 1997.

Jordà, G., Marbà, N., and Duarte, C. M.: Mediterranean seagrass vulnerable to regional climate warming, Nat. Clim. Change, 2, 821-824, 2012.

Kleypas, J. A., Anthony, K. R. N., and Gattuso, J. P.: Coral reefs modify their seawater carbon chemistry - case study from a barrier reef (Moorea, French Polynesia), Glob. Chan. Biol., 17, 3667-3678, 2011.

Koch, E. W.: Hydrodynamics, Diffusion-Boundary Layers and Photosynthesis of the Seagrasses Thalassia testudinum and Cymodocea nodosa, Mar. Biol., 118, 767-776, 1994.

Madsen, T. V., Sand-Jensen, K., and Beer, S.: Comparison of photosynthetic performance and carboxylation capacity in a range of aquatic macrophytes of different growth forms, Aquat. Bot., 44, 373-384, 1993.

Madsen, T. V., Maberly, S. C., and Bowes, G.: Photosynthetic acclimation of submersed angiosperms to $\mathrm{CO}_{2}$ and $\mathrm{HCO}_{3}^{-}$, Aquat. Bot., 53, 15-30, 1996.

Marbà, N. and Duarte, C. M.: Rhizome elongation and seagrass clonal growth, Mar. Ecol. Prog. Ser., 174, 269-280, 1998.

Marbà, N. and Duarte, C. M.: Mediterranean warming triggers seagrass (Posidonia oceanica) shoot mortality, Glob. Chan. Biol., 16, 2366-2375, 2010.

Mehrbach, C., Culberson, C. H., Hawley, J. E., and Pytkowicz, R. M.: Measurement of the apparent dissociation constants of carbonic acid in seawater at atmospheric pressure, Limnol. Oceanogr., 18, 897-907, 1973.

Menéndez, M., Martìnez, M., and Comìn, F. A.: A comparative study of the effect of $\mathrm{pH}$ and inorganic carbon resources on the photosynthesis of three floating macroalgae species of a Mediterranean coastal lagoon, J. Exp. Mar. Biol. Ecol., 256, 123-136, 2001.

Mercado, J. and Gordillo, F.: Inorganic carbon acquisition in algal communities: are the laboratory data relevant to the natural ecosystems?, Photosynth. Res., 109, 257-267, 2011.

Middelboe, A. L. and Hansen, P. J.: Direct effects of $\mathrm{pH}$ and inorganic carbon on macroalgal photosynthesis and growth, Mar. Biol. Res., 3, 134-144, 2007.

Orr, J. C., Fabry, V. J., Aumont, O., Bopp, L., Doney, S. C., Feely, R. A., Gnanadesikan, A., Gruber, N., Ishida, A., Joos, F., Key, R. M., Lindsay, K., Maier-Reimer, E., Matear, R., Monfray, P., Mouchet, A., Najjar, R. G., Plattner, G.-K., Rodgers, K. B., Sabine, C. L., Sarmiento, J. L., Schlitzer, R., Slater, R. D., Totterdell, I. J., Weirig, M.-F., Yamanaka, Y., and Yool, A.: Anthropogenic ocean acidification over the twenty-first century and its impact on calcifying organisms, Nature, 437, 681-686, 2005.

Orth, R. J., Carruthers, T. J. B., Dennison, W. C., Duarte, C. M., Fourqurean, J. W., Heck, K. L., Hughes, A. R., Kendrick, G. A., Kenworthy, W. J., Olyarnik, S., Short, F. T., Waycott, M., and Williams, S. L.: A global crisis for seagrass ecosystems, Bioscience, 56, 987-996, 2006.

Pierrot, D., Lewis, E., and Wallace, D. W. R.: MS Excel Program Developed for $\mathrm{CO}_{2}$ System Calculations. In: ORNL/CDIAC105a, Carbon Dioxide Information Analysis Center, Oak Ridge National Laboratory, US Department of Energy, Oak Ridge, Tennessee, 2006.

R Development Core Team: R: A language and environment for statistical computing, R Foundation for Statistical Computing, Vienna, Austria, 2011.

Schmalz, R. F. and Swanson, F. J.: Diurnal variations in the carbonate saturation of seawater, J. Sediment. Res., 39, 255-267, 1969.

Semesi, I. S., Beer, S., and Björk, M.: Seagrass photosynthesis controls rates of calcification and photosynthesis of calcareous macroalgae in a tropical seagrass meadow, Mar. Ecol. Prog. Ser., 382, 41-47, 2009.

Short, F. T. and Neckles, H. A.: The effects of global climate change on seagrasses, Aquat. Bot., 63, 169-196, 1999.

Smith, S. V. and Atkinson, M. J.: Phosphorus limitation of net production in a confined aquatic ecosystem, Nature, 307, 626-627, 1984.

Talmage, S. C. and Gobler, C. J.: Effects of past, present, and future ocean carbon dioxide concentrations on the growth and survival 
of larval shellfish, P. Natl. Acad. Sci. USA, 107, 17246-17251, 2010.

Unsworth, R. K. F., Collier, C. J., Henderson, G. M., and McKenzie, L. J.: Tropical seagrass meadows modify seawater carbon chemistry: Implications for coral reefs impacted by ocean acidification, Environ. Res. Lett., 7, 9 pp., 2012.

Waldbusser, G., Voigt, E., Bergschneider, H., Green, M., and Newell, R. E.: Biocalcification in the Eastern Oyster (Crassostrea virginica) in Relation to Long-term Trends in Chesapeake Bay pH, Est. Coas., 34, 221-231, 2011.
Waycott, M., Duarte, C. M., Carruthers, T. J. B., Orth, R. J., Dennison, W. C., Olyarnik, S., Calladine, A., Fourqurean, J. W., Heck, K. L., Jr., Hughes, A. R., Kendrick, G. A., Kenworthy, W. J., Short, F. T., and Williams, S. L.: Accelerating loss of seagrasses across the globe threatens coastal ecosystems, P. Natl. Acad. Sci. USA, 106, 12377-12381, 2009. 